Article

\title{
Antimicrobial Effect and Probiotic Potential of Phage Resistant Lactobacillus plantarum and its Interactions with Zoonotic Bacterial Pathogens
}

\author{
Vinod Nagarajan ${ }^{1}$, Mengfei Peng ${ }^{1}$, Zajeba Tabashsum ${ }^{2}$, Serajus Salaheen ${ }^{1}$, Joselyn Padilla ${ }^{2}$ \\ and Debabrata Biswas 1,2,3,* \\ 1 Department of Animal and Avian Sciences, University of Maryland, College Park, MD 20742, USA; \\ biovinz@gmail.com (V.N.); murphy7@umd.edu (M.P.); salaheen@umd.edu (S.S.) \\ 2 Biological Sciences Program, University of Maryland, College Park, MD 20742, USA; \\ ztabashs@terpmail.umd.edu (Z.T.); joselyn0520@hotmail.com (J.P.) \\ 3 Centre for Food Safety and Security Systems, University of Maryland, College Park, MD 20742, USA \\ * Correspondence: dbiswas@umd.edu; Tel.: +1-301-405-3791; Fax: +1-301-405-7980
}

Received: 20 April 2019; Accepted: 3 June 2019; Published: 5 June 2019

check for updates

\begin{abstract}
Development of phage-resistant probiotic particularly Lactobacillus is an alternative approach to enhance their beneficial effects as in animal feed supplements. In this study, we developed phage-resistant Lactobacillus plantarum $\left(\mathrm{LP}^{+P R}\right)$ mutant and compared their antimicrobial effects and probiotic potential against zoonotic bacterial pathogens including Salmonella enterica serovar Typhimurium, enterohemorrhagic Escherichia coli (EHEC), Staphylococcus aureus, and Listeria monocytogenes with phage-sensitive L. plantarum (LP) strain. $\mathrm{LP}^{+P R}$ strain showed markedly higher growth rate than wild-type LP strain. In co-culture with $\mathrm{LP}^{+P R}$ and in the presence of cell-free cultural supernatants (CFCSs) of $\mathrm{LP}^{+P R}$, the growth of $S$. Typhimurium, EHEC, S. aureus, and L. monocytogenes were reduced significantly $(P<0.05)$. The adhesion ability of $\mathrm{LP}^{+P R}$ was slightly higher than the LP on human epithelial INT-407 cells. Most importantly, $\mathrm{LP}^{+P R}$ strain significantly inhibited the adhesive and invasive abilities of all four zoonotic pathogens to INT-407 cells $(P<0.05)$. Moreover, real-time $\mathrm{qPCR}$ revealed that in the presence of $\mathrm{LP}^{+P R}$ strain or its CFCSs, expression of virulence genes of these zoonotic bacterial pathogens were suppressed significantly $(P<0.05)$. These findings suggest that the $\mathrm{LP}^{+P R}$ strain is capable of inhibiting major zoonotic bacterial pathogens efficiently and would be a potential candidate for industrial usage in animal production or fermentation.
\end{abstract}

Keywords: probiotic; Lactobacillus plantarum; bacteriophage; zoonotic bacterial pathogen

\section{Introduction}

Lactic acid bacteria (LAB) represents the important group of probiotic due to their ability to exhibit wide-range of health-promoting effects specifically improving gut health and immunity [1]. Lactobacillus are most common and widely used probiotic bacteria in the food and dairy industries [2] and the common functional species are Lactobacillus plantarum (LP), L. acidophilus, L. casei, L. delbrueckii, L. fermentum, L. johnsonii, L. paracasei, L. reuteri, L. rhamnosus, and L. salivarius [3]. Further, benefits of probiotics vastly depend on the metabolites, for example, lactic acid, acetic acid, propionic acid, succinic acid, hydrogen peroxide, carbon dioxide, acetaldehyde, acetoine, reuterin, reutricyclin, and bacteriocins, as well as their ability to produce low molecular weight antimicrobial substances $[4,5]$. Numerous studies have shown that probiotics help to maintaining the balance of the intestinal microflora, promoting innate and adaptive immune responses, modulating the intestinal immune system [6], detoxifying colonic toxins, lowering serum cholesterol levels [7], promoting lactose tolerance, inhibiting bacterial toxin, producing metabolites essential to the function of intestinal epithelial cells [8], 
preventing and treating diarrhea, food allergies, acute gastritis, and control of total cholesterol and ratio of LDL and HDL [9].

Commonly LP alone or in combination with other probiotics is used as a starter culture in different fermented foods and beverages as well as feed supplement for farm animal production [10]. LP has proven to possess the ability to grow and survive in various environmental conditions and colonize well in the intestinal tract of humans and other mammals [11,12]. The zoonotic pathogens such as Salmonella enterica serovar Typhimurium, enterohaemorrhagic Escherichia coli (EHEC), Staphylococcus aureus, and Listeria monocytogenes can cause diarrhea and gastroenteritis in humans and animals. Thus, LP can block adhesion of enteric pathogens, by attaching themselves on the surface of the intestinal epithelial cells and preventing the entry of those pathogenic bacteria to gastrointestinal epithelium [13-15]. In addition, LP showed antioxidant and antimicrobials properties in minced chicken meat during fermentation [16]. Several other studies have also shown that LP could reduce diarrheal infections, abdominal pain and constipation associated with irritable bowel syndrome, bloating, and inhibit the entry of zoonotic enteric pathogens into Caco-2 cells $[17,18]$.

Bacteriophage infections are one of the serious threats to the activity of LAB in the global dairy industry. Particularly, the dairy industry has been accepted the problem with phage contamination in dairy-based foods [19]. The beneficial activities of probiotics can be extremely affected when phage contamination occurs. Especially, phage contamination can lead to significant economic loss, waste of ingredients, low product quality, growth of spoilage and bacterial pathogens, total production loss [20]. In addition, phage populations can also increase if the phage-sensitive probiotic strains are used as a starter culture. Therefore, the development of phage-resistant probiotic strains from phage-sensitive probiotic strains would be excellent alternative strategies to minimize these problems.

The objective of this study was to develop and characterize the probiotic potential of phage-resistant L. plantarum $\left(\mathrm{LP}^{+P R}\right)$ strain and their growth inhibitory effect on zoonotic bacterial enteric pathogens, such as $S$. Typhimurium, EHEC, S. aureus, and L. monocytogenes. In addition, we examined the adherence properties of $L P^{+P R}$ strain by using INT-407 cell model. We have also investigated the probiotic properties of this $L P^{+P R}$ in reducing host cell (INT-407) and pathogen interactions and virulence gene expression of zoonotic pathogens in the presence of $\mathrm{LP}^{+P R}$ strain by quantitative real-time PCR (RT-qPCR).

\section{Materials and Methods}

\subsection{Bacterial Strains and Growth Conditions}

A bacteriophage sensitive Lactobacillus plantarum (LP, ATCC39542), and four enteric bacterial pathogens including Salmonella enterica serovar Typhimurium (ATCC14028), enterohemorrhagic Escherichia coli EDL933 (EHEC, ATCC700927), Staphylococcus aureus (ATCC29740) and Listeria monocytogenes (ATCC19115) were used in this study. In addition, phage-resistant mutant strain was generated from phage sensitive LP and named as $L P^{+P R}$. Both $L P$ and $L P^{+P R}$ were grown on de Man Rogosa Sharpe (MRS) agar or broth overnight at $37^{\circ} \mathrm{C}$ under aerobic condition with $5 \% \mathrm{CO}_{2}$ (Thermo Fisher Scientific, MA, USA). The bacterial pathogens S. Typhimurium, EHEC, S. aureus, and L. monocytogenes were grown on Luria-Bertani (LB) agar/broth, MacConkey agar, Tryptic Soy agar (TSA), and Brain Heart Infusion (BHI) agar (EMD Chemicals Inc., NJ, USA), respectively, and incubated overnight at $37^{\circ} \mathrm{C}$ under aerobic conditions (Thermo Fisher Scientific, MA, USA).

\subsection{Bacteriophage Culture and Propagation}

The commercial J1 bacteriophage (ATCC 27139-B1) was purchased from American Type Culture Collection, suspended in saline magnesium buffer (SM buffer) and stored at $4{ }^{\circ} \mathrm{C}$. J1 bacteriophage was propagated in MRS broth containing host strain LP at $37^{\circ} \mathrm{C}$ under aerobic condition with $5 \% \mathrm{CO}_{2}$ for $48 \mathrm{~h}$. The culture was centrifuged at $3000 \times \mathrm{g}$ for $20 \mathrm{~min}$ and filtered through a $0.2 \mu \mathrm{m}$ sterilized filter. The bacteriophages were further purified following method previously described [21]. 


\subsection{Mammalian Cell and Culture Conditions}

Human epithelium cell line (INT-407 CCL-6) was purchased from American Type Culture Collection and cultured according to the method described previously with slight modifications [22]. Briefly, cells were routinely cultured in Dulbecco's modified Eagle medium (DMEM) (HyClone Laboratories Inc., UT, USA) supplemented with $10 \%$ fetal bovine serum (FBS) and $50 \mu \mathrm{g} / \mathrm{mL}$ gentamycin. Cells were grown at $37{ }^{\circ} \mathrm{C}$ in 24-well tissue culture plates (BD Falcon, NJ, USA) in a $5 \% \mathrm{CO}_{2}-95 \%$ humidity atmosphere. The post-confluent INT-407 epithelial cell monolayers were washed three times with sterile PBS and cell culture medium was replaced by fresh DMEM every $48 \mathrm{~h}$.

\subsection{Isolation of Phage-Resistant L. plantarum $\left(L P^{+P R}\right)$ Mutant}

To isolate $L P^{+P R}$ mutant strain, the agar plate method was used as described previously with some modifications [23]. An overnight culture of LP in MRS supplemented with $10 \mathrm{mmol} / \mathrm{L} \mathrm{CaCl}_{2}$ was infected with different ration of J1 bacteriophage (Multiplicity of infection: 1, 0.1, and 0.01). An aliquot of $0.5 \mathrm{~mL}$ overnight liquid culture of sensitive strain was inoculated in $4.5 \mathrm{~mL} 0.5 \%$ MRS soft agar with $10 \mathrm{mmol} / \mathrm{L} \mathrm{CaCl}_{2}$. Pre-warmed MRS agar plate was overlaid with the $5 \mathrm{~mL}$ mixture mentioned above. After the soft agar solidified, $25 \mu \mathrm{L}$ of the J1 phage suspension was spotted on the soft agar, followed by incubation at $37{ }^{\circ} \mathrm{C}$ with $5 \% \mathrm{CO}_{2}$ for $48 \mathrm{~h}$. After incubation, survived colony of LP was isolated and cultured on fresh MRS agar plate for three more consecutive phage-resistant selection described above. The isolated colony after three consecutive selection was isolated, cultured in MRS broth, and stored as presumptive $\mathrm{LP}^{+P R}$ strain.

To confirm $\mathrm{LP}^{+P R}$ strain, the genomic DNA of J1 bacteriophage, $\mathrm{LP}$ and $\mathrm{LP}^{+P R}$ strains were isolated using DNeasy Blood \& Tissue Kit (Qiagen, CA, USA). Gene encoding for phage tail protein ( $p t p$ ) in J1 bacteriophage was targeted for $\mathrm{LP}^{+P R}$ confirmation. PCR was performed in Mastercycler (Eppendorf, NY, USA) and programmed for initial 2 min $94{ }^{\circ} \mathrm{C}$ followed by 40 cycles of $94{ }^{\circ} \mathrm{C}$ for $1 \mathrm{~min}, 45^{\circ} \mathrm{C}$ for $30 \mathrm{~s}$, and $72{ }^{\circ} \mathrm{C}$ for $2 \mathrm{~min}$, followed by a final elongation of $10 \mathrm{~min}$ at $72{ }^{\circ} \mathrm{C}$. Primers were synthesized from Eurofins MWG Operon LLC (Louisville, KY, USA). PCR products were resolved by electrophoresis through 1.5\% agarose (Sigma-Aldrich) gel at $120 \mathrm{~V}$ for $45 \mathrm{~min}$ in Tris-acetate-EDTA (TAE) buffer.

\subsection{Growth and Survival of $L P$ and $L P^{+P R}$ Strains}

$\mathrm{LP}$ and $\mathrm{LP}^{+P R}$ strains were grown overnight at $37^{\circ} \mathrm{C}$ in MRS broth. The overnight cultured bacterial strains were centrifuged, washed three times with PBS and adjusted to concentration at $1 \times 10^{6} \mathrm{CFU} / \mathrm{mL}$. Both bacterial suspensions were diluted to 1:10 into fresh MRS broth and incubated at $37^{\circ} \mathrm{C}$. Samples were taken at $0,6,12,24,48$, and $72 \mathrm{~h}$ intervals, serially-diluted, and plated on MRS agar. Plates were incubated under micro-aerophilic condition at $37^{\circ} \mathrm{C}$ for $48 \mathrm{~h}$ and surviving bacteria were counted as colony-forming units per milliliter ( $\mathrm{CFU} / \mathrm{mL})$.

\subsection{Co-Culture of $L P$ or $L P^{+P R}$ Strain with Zoonotic Bacterial Pathogens}

$\mathrm{LP}, \mathrm{LP}^{+P R}, \mathrm{~S}$. Typhimurium, EHEC, S. aureus, and L. monocytogenes were grown overnight at $37^{\circ} \mathrm{C}$ as described above. Aliquot of $400 \mu \mathrm{L} \mathrm{LP}$ or LP ${ }^{+P R}$ strains $\left(1 \times 10^{8} \mathrm{CFU} / \mathrm{mL}\right)$ was co-cultured with $400 \mu \mathrm{L}$ of enteric pathogens $\left(1 \times 10^{5} \mathrm{CFU} / \mathrm{mL}\right)$ in $3.2 \mathrm{~mL}$ of DMEM supplemented with $5 \%$ heat-inactivated FBS. Cultures were incubated at $37^{\circ} \mathrm{C}$ under aerobic condition and samples were taken at $0,6,24$, and $48 \mathrm{~h}$ time points. Bacterial counts were determined by plating of 10 -fold serial dilutions and spread on specific agars.

\subsection{Cell-Free Cultural Supernatants (CFCSs) of LP and LP+PR Strains on Growth of Zoonotic Pathogens}

Overnight $(18 \mathrm{~h})$ liquid cultures of $\mathrm{LP}$ and $\mathrm{LP}^{+P R}$ strains were grown in DMEM supplemented with 5\% FBS and centrifuged at 4000 $\times g$ for $20 \mathrm{~min}$ (Thermo fisher Scientific Inc., MA, USA). Cells were washed twice with PBS and CFCSs were further filtered by sterile syringe $0.2 \mu \mathrm{m}$ filter (VWR Inc, $\mathrm{PA}, \mathrm{USA})$ and stored at $4{ }^{\circ} \mathrm{C}[24,25]$. The bacterial cell suspension containing $400 \mu \mathrm{L}\left(1 \times 10^{5} \mathrm{CFU} / \mathrm{mL}\right)$ 
of S. Typhimurium, EHEC, S. aureus, or L. monocytogenes and $400 \mu \mathrm{L}$ CFCSs collected from LP or LP ${ }^{+P R}$ strain were inoculated in a separate culture tubes with $3.2 \mathrm{~mL}$ of DMEM and $5 \% \mathrm{FBS}$. The culture tubes were incubated at $37^{\circ} \mathrm{C}$ and samples were plated on specific agar plates at $0,6,24$, and $48 \mathrm{~h}$. Plates were incubated at $37^{\circ} \mathrm{C}$ for $24 \mathrm{~h}$ and surviving bacteria were counted as $\mathrm{CFU} / \mathrm{mL}$.

\subsection{Host Cells-LP or LP ${ }^{+P R}$ Interactions}

The adherence activity of LP or $\mathrm{LP}^{+\mathrm{PR}}$ mutant strains were performed as described previously with some modifications [26]. The adherence abilities of LP and $\mathrm{LP}^{+P R}$ strains were examined using INT-407 cells. For adhesion assay, the INT-407 cells were seeded at a concentration of $2 \times 10^{5}$ cells/well in 24-well plate with $900 \mu \mathrm{L}$ DMEM containing $10 \%$ FBS. The bacterial cells were cultured at $37^{\circ} \mathrm{C}$ for overnight, centrifuged, and washed three times with sterile PBS before the adhesion assay. $100 \mu \mathrm{L}$ of LP or LP ${ }^{+P R}$ strains $\left(1 \times 10^{8} \mathrm{CFU} / \mathrm{mL}\right)$ suspended in $1 \mathrm{~mL}$ DMEM medium with $10 \%$ FBS were added to wells and then plates were incubated at $37^{\circ} \mathrm{C}$ in $5 \% \mathrm{CO}_{2}-95 \%$ air for $2 \mathrm{~h}$. After incubation, the unattached cells were washed three times with sterile PBS (pH 7.4) and cells were lysed by addition of $0.1 \%$ Triton X-100 for $15 \mathrm{~min}$. The adherence level of LP and $\mathrm{LP}^{+P R}$ strains was measured by plating serial dilutions adhered bacteria on MRS agar. The plates were incubated at $37^{\circ} \mathrm{C}$ for $48 \mathrm{~h}$.

\subsection{Inhibition of Adherence and Invasion of Zoonotic Enteric Pathogens with CFCSs Collected from LP and $L P^{+P R}$ Strains}

In order to determine cell adhesion and invasion of S. Typhimurium, EHEC, S. aureus, and L. monocytogenes by co-culture and CFCSs of LP or $\mathrm{LP}^{+P R}$ strains was carried out following the method described previously [22]. The INT-407 cells grown in 24-well plate with $800 \mu \mathrm{L}$ DMEM containing $10 \%$ FBS were pre-treated with $100 \mu \mathrm{L}$ DMEM (control), $1 \times 10^{8} \mathrm{CFU} / \mathrm{mL}$ of $\mathrm{LP}$ or $\mathrm{LP}^{+P R}, \mathrm{CFCSs}$ of $\mathrm{LP}$ or $\mathrm{LP}^{+P R}$ incubated at $37^{\circ} \mathrm{C}$ for $1 \mathrm{~h}$. After pre-treatment, INT-407 cells were washed three times with sterile PBS and fresh DMEM with 10\% FBS was added. A $100 \mu \mathrm{L}$ of enteric pathogenic bacteria $\left(1 \times 10^{5} \mathrm{CFU} / \mathrm{mL}\right)$ were then added to the well. After an additional $2 \mathrm{~h}$ incubation, the unattached cells were washed three times with sterile PBS. The cells were lyzed by $0.1 \%$ Triton X-100 for $15 \mathrm{~min}$, serially diluted, and plated on specific agar plates for enumerating the adhesive bacterial cells. Cell invasive activity was measured by further $1 \mathrm{~h}$ incubation of washed monolayers in DMEM containing $10 \%$ FBS and $100 \mu \mathrm{g} / \mathrm{mL}$ gentamycin. The cells were washed three times with PBS and lysed with Triton X-100, serially diluted, and plated on specific agars.

\subsection{RNA Extraction and cDNA Synthesis}

All four zoonotic pathogenic bacteria were grown overnight in the presence and absence of CFCSs of LP or LP ${ }^{+P R}$ strains, and RNA was extracted according to the methods of Peng et al. (2015) [22]. Bacterial cells were washed three times with ice-cold PBS and $1 \mathrm{~mL}$ TRIzol reagent (Life Technologies Co., Carlsbad, CA, USA) was added to lyse the cells for $5 \mathrm{~min}$ at room temperature. After the cells were lysed, $200 \mu \mathrm{L}$ of chloroform was added and samples were mixed and kept at room temperature for $3 \mathrm{~min}$. The samples were centrifuged at $13,000 \times \mathrm{g}$ for $15 \mathrm{~min}$ at $4{ }^{\circ} \mathrm{C}$. After centrifugation, the supernatant was collected and mixed with $500 \mu \mathrm{L}$ of isopropanol and allowed to stand for $10 \mathrm{~min}$ at room temperature before being centrifuged at $13,000 \times \mathrm{g}$ for $15 \mathrm{~min}$ at $4{ }^{\circ} \mathrm{C}$. The supernatant was removed, washed with $1 \mathrm{~mL}$ of $75 \%$ ethanol and centrifuged at $7000 \times g$ for $5 \mathrm{~min}$ at $4{ }^{\circ} \mathrm{C}$. The remaining supernatant was removed, and the pellets were placed in bio-safety cabinet for $10 \mathrm{~min}$ to dry. The RNA pellet was fully dissolved in $50 \mu \mathrm{L}$ RNase-free water and quantified by a NanoDrop spectrophotometer (Thermo Fisher Scientific).Using a qScript cDNA SuperMix protocol (Quanta Biosciences, MD, USA), one $\mu \mathrm{g}$ of total RNA was mixed with qScript cDNA SuperMix containing optimized concentration of $\mathrm{MgCl}_{2}$, $\mathrm{dNTPs}$, random primers, qScript reverse transcriptase, and RNase inhibitor protein. Subsequently, the reaction mixture was incubated at $25^{\circ} \mathrm{C}$ for $5 \mathrm{~min}$, $42{ }^{\circ} \mathrm{C}$ for $30 \mathrm{~min}$, and $85^{\circ} \mathrm{C}$ for $5 \mathrm{~min}$ to terminate the reaction. Finally, the synthesized cDNA was stored at $-20^{\circ} \mathrm{C}$ until further use. 


\subsection{Quantitative RT-PCR Assay}

The PCR reaction mixture containing $10 \mu \mathrm{L}$ of PerfeCTa STBR Green FastMix, $1 \mu \mathrm{L}$ of forward and reverse primers (100 nM), $2 \mu \mathrm{L}$ of cDNA (10 ng), and $4 \mu \mathrm{L}$ of RNase-free water were amplified using an Eco Real-Time PCR system (Illumine, CA, USA). The reaction conditions were as follows: $95^{\circ} \mathrm{C}$ for $30 \mathrm{~s}$, followed by 40 cycles at $95^{\circ} \mathrm{C}$ for $5 \mathrm{~s}, 55^{\circ} \mathrm{C}$ for $15 \mathrm{~s}$, and $72{ }^{\circ} \mathrm{C}$ for $10 \mathrm{~s}$. All the virulence genes were estimated by comparative fold change. The $\mathrm{CT}$ values of genes were normalized to the housekeeping gene 16s rRNA and the relative expression levels of target genes were compared between control and treatment. The fold change in terms of expression of each individual virulence gene was calculated as $\Delta \triangle \mathrm{CT}=(\mathrm{CT}($ target mRNA $)-\mathrm{CT}($ reference mRNA $))$ treatment $-(\mathrm{CT}($ target mRNA $)-$ $\mathrm{CT}($ reference mRNA))control [27].

\subsection{Statistical Analysis}

All statistical analyses were performed with one-way ANOVA using SPSS software (version 20.0) and data were expressed as mean \pm standard deviation. Data were analyzed at the significance level of $P<0.05$.

\section{Results}

\subsection{Confirmation of Bacteriophage Resistant $L P^{+P R}$ Strain}

To confirm the bacteriophage resistance characteristics of $L P^{+P R}$ strain, we targeted J1 bacteriophage $p t p$ gene in $\mathrm{LP}^{+P R}$ strain genome. Genomic DNA from wild-type LP and J1 bacteriophage containing $\mathrm{LP}^{+P R}$ strain as well as $\mathrm{J} 1$ bacteriophage were amplified and visualized in the gel electrophoresis image. We found that $\mathrm{LP}^{+P R}$ genome contained the $300 \mathrm{bp}$ of $p t p$ gene of $\mathrm{J} 1$ bacteriophage (Figure S1). These results revealed that phage-resistant mutant strain was successfully developed from the phage-sensitive wild-type LP strain by J1 bacteriophage.

\subsection{Comparative Growth and Survival Ability of $L P$ and $L P^{+P R}$ Strains}

The growth and survival ability of $L P$ and $L P^{+P R}$ strains were compared by enumerating viable cell counts after $0,6,12,24,48$, and $72 \mathrm{~h}$ time intervals and shown in Figure $1 . \mathrm{LP}^{+P R}$ strain showed greater survival rate than the wild-type LP strain after $12 \mathrm{~h}$ incubation. Most importantly, the bacteriophage resistant $\mathrm{LP}^{+P R}$ strain $(10.46 \log \mathrm{CFU} / \mathrm{mL}$ ) exhibited significantly higher survival rate in comparison to wild-type LP strain $(9.41 \log \mathrm{CFU} / \mathrm{mL})$ at $24 \mathrm{~h}(P<0.05)$. These results demonstrate that $\mathrm{LP}$ and $\mathrm{LP}^{+P R}$ strain was able to grow and survive under in vitro condition but $\mathrm{LP}^{+P R}$ could grow and survive better than the wild-type LP strain.

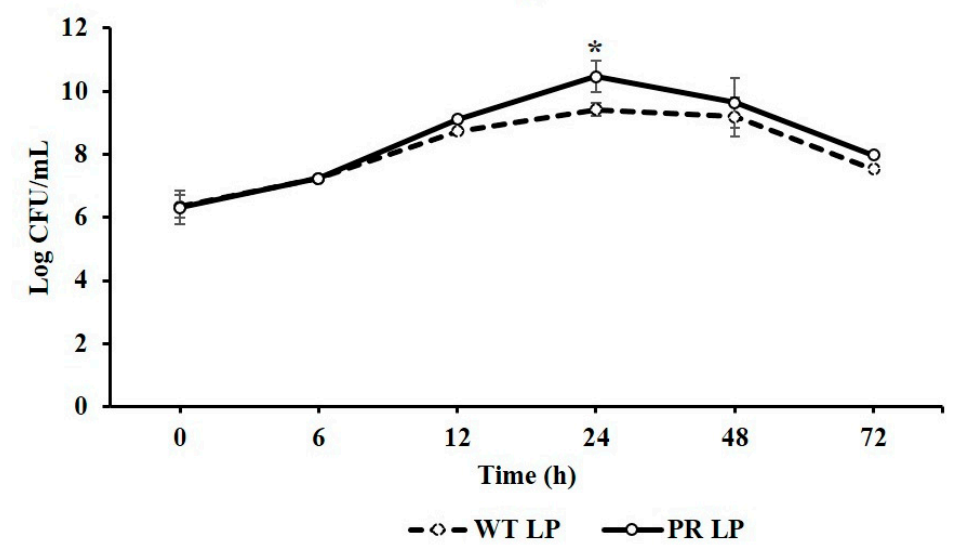

Figure 1. Growth pattern of wild-type Lactobacillus plantarum (LP) and phage-resistant Lactobacillus plantarum $\left(\mathrm{LP}^{+P R}\right)$ strains at $0,6,12,24,48$, and $72 \mathrm{~h}$. Error bars indicate standard deviation from 6 parallel trials. Asterisks indicate the significant growth when compared to wild-type LP strain at $P<0.05$. 


\subsection{Competitive Inhibition of Zoonotic Pathogens in Co-Culture Condition}

The growth of $S$. Typhimurium, EHEC, S. aureus, and L. monocytogenes in the presence or absence of $\mathrm{LP}$ or $\mathrm{LP}^{+P R}$ strains was monitored at $37^{\circ} \mathrm{C}$. Growth inhibition of all four enteric pathogens are presented in Figure 2. In this study, we found that both LP and $L P^{+P R}$ strains significantly inhibited the growth of bacterial enteric pathogens after $24 \mathrm{~h}$ of incubation. Moreover, the number of viable EHEC and S. aureus in co-culture with either LP or $L P^{+P R}$ strain decreased significantly after $6 \mathrm{~h}$ of incubation $(P<0.05)$. We observed that wild-type LP and mutant $\mathrm{LP}^{+P R}$ significantly inhibited the growth of $S$. Typhimurium by 2.88 and $3.21 \log$ CFU/mL, EHEC by 3.38 and $3.22 \log C F U / m L$, S. aureus by 4.63 and $5.16 \log \mathrm{CFU} / \mathrm{mL}$ and L. monocytogenes by 3.86 and $4.68 \log \mathrm{CFU} / \mathrm{mL}$, respectively at $48 \mathrm{~h}$.

(A)
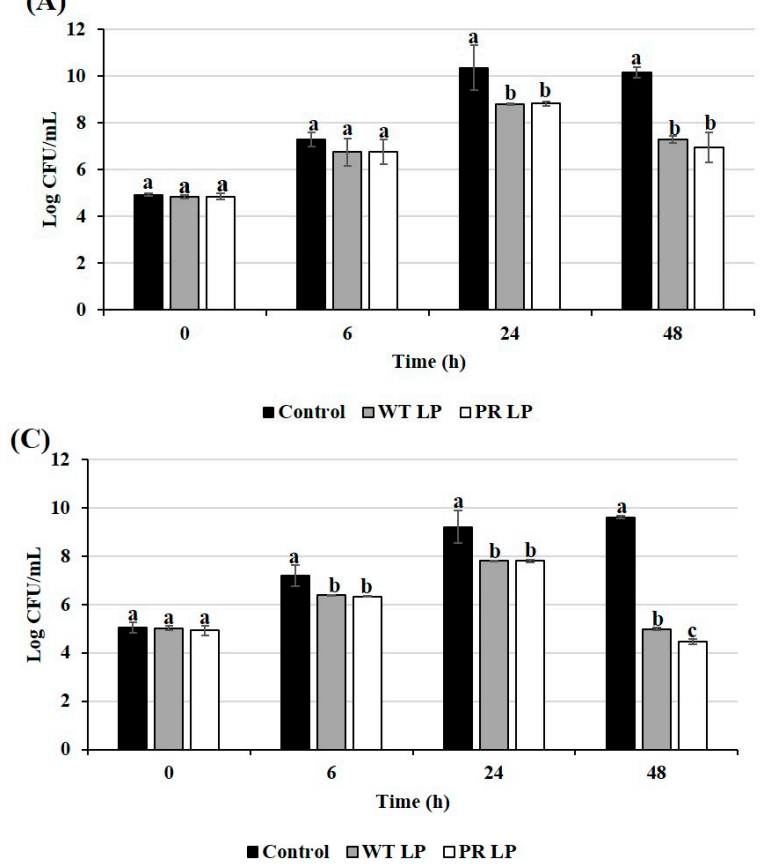
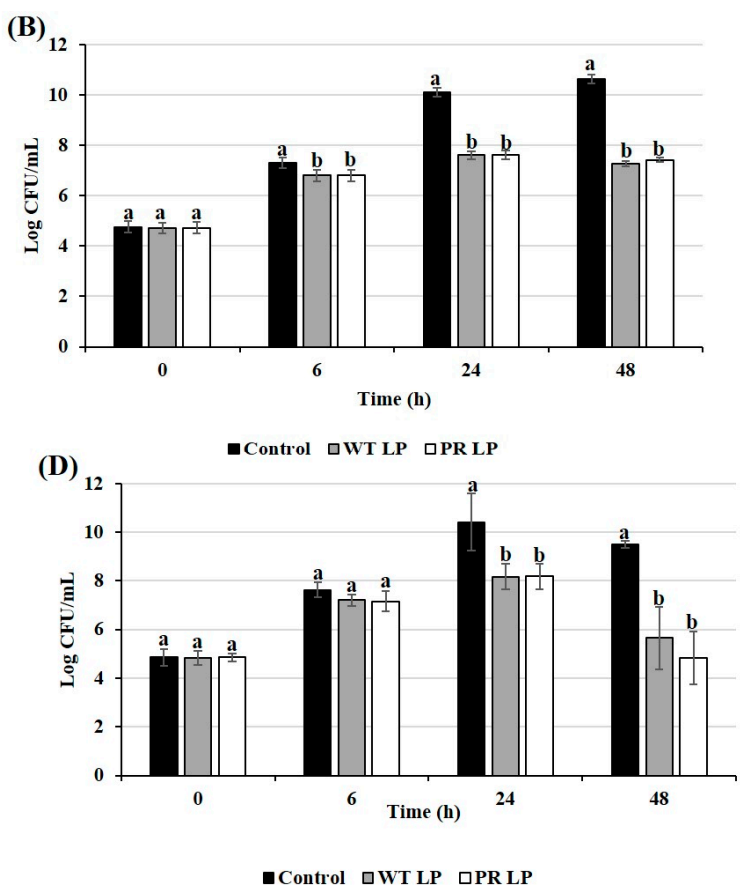

Figure 2. Growth inhibition of $S$. Typhimurium (A), enterohemorrhagic Escherichia coli (EHEC) (B), S. aureus (C), and L. monocytogenes (D) in co-culture of wild-type LP and $\mathrm{LP}^{+P R}$ strains at $0,6,24$, and $48 \mathrm{~h}$. Error bars indicate standard deviation from 6 parallel trials. Different letters $(\mathrm{a}-\mathrm{c})$ at each time point indicate the significant growth reduction when compared to control at $P<0.05$.

\subsection{Effects of CFCSs of $L P$ and $L P^{+P R}$ on Growth of Zoonotic Pathogens}

The either CFCSs collected from LP or $\mathrm{LP}^{+P R}$ showed growth inhibitory effects on $S$. Typhimurium, EHEC, S. aureus, and L. monocytogenes (Figure 3). Both CFCSs collected from LP or LP ${ }^{+P R}$ showed tendency to inhibit the growth of EHEC at $6 \mathrm{~h}$. After $24 \mathrm{~h}$, CFCS collected from $\mathrm{LP}^{+P R}$ significantly reduced the growth of $S$. Typhimurium (1.93 $\log \mathrm{CFU} / \mathrm{mL})$, EHEC (2.99 $\log \mathrm{CFU} / \mathrm{mL})$, S. aureus (2.58 $\log \mathrm{CFU} / \mathrm{mL}$ ), and L. monocytogenes $(2.93 \log \mathrm{CFU} / \mathrm{mL}$ ). Compared to the control (only cell culture medium with $S$. aureus) and CFCS collected from wild-type LP, CFCSs of the LP ${ }^{+P R}$ significantly inhibited the growth of S. aureus after $48 \mathrm{~h}$ (Figure 3C). CFCSs collected from wild-type LP at $48 \mathrm{~h}$ time point significantly reduced growth of $S$. Typhimurium, EHEC, S. aureus, and L. monocytogenes $2.91 \log \mathrm{CFU} / \mathrm{mL}, 3.23 \log \mathrm{CFU} / \mathrm{mL}, 2.70 \log \mathrm{CFU} / \mathrm{mL}$, and $4.41 \log \mathrm{CFU} / \mathrm{mL}$, respectively (Figure 3) compared to the control. In the same study, CFCSs collected from $\mathrm{LP}^{+P R}$ showed more intensive reduction of growth of $S$. Typhimurium (3.53 $\log \mathrm{CFU} / \mathrm{mL})$, EHEC (3.12 $\log \mathrm{CFU} / \mathrm{mL})$, S. aureus (3.95 $\log \mathrm{CFU} / \mathrm{mL}$ ), and L. monocytogenes (4.43 $\log \mathrm{CFU} / \mathrm{mL}$ ) at $48 \mathrm{~h}$ time point. 

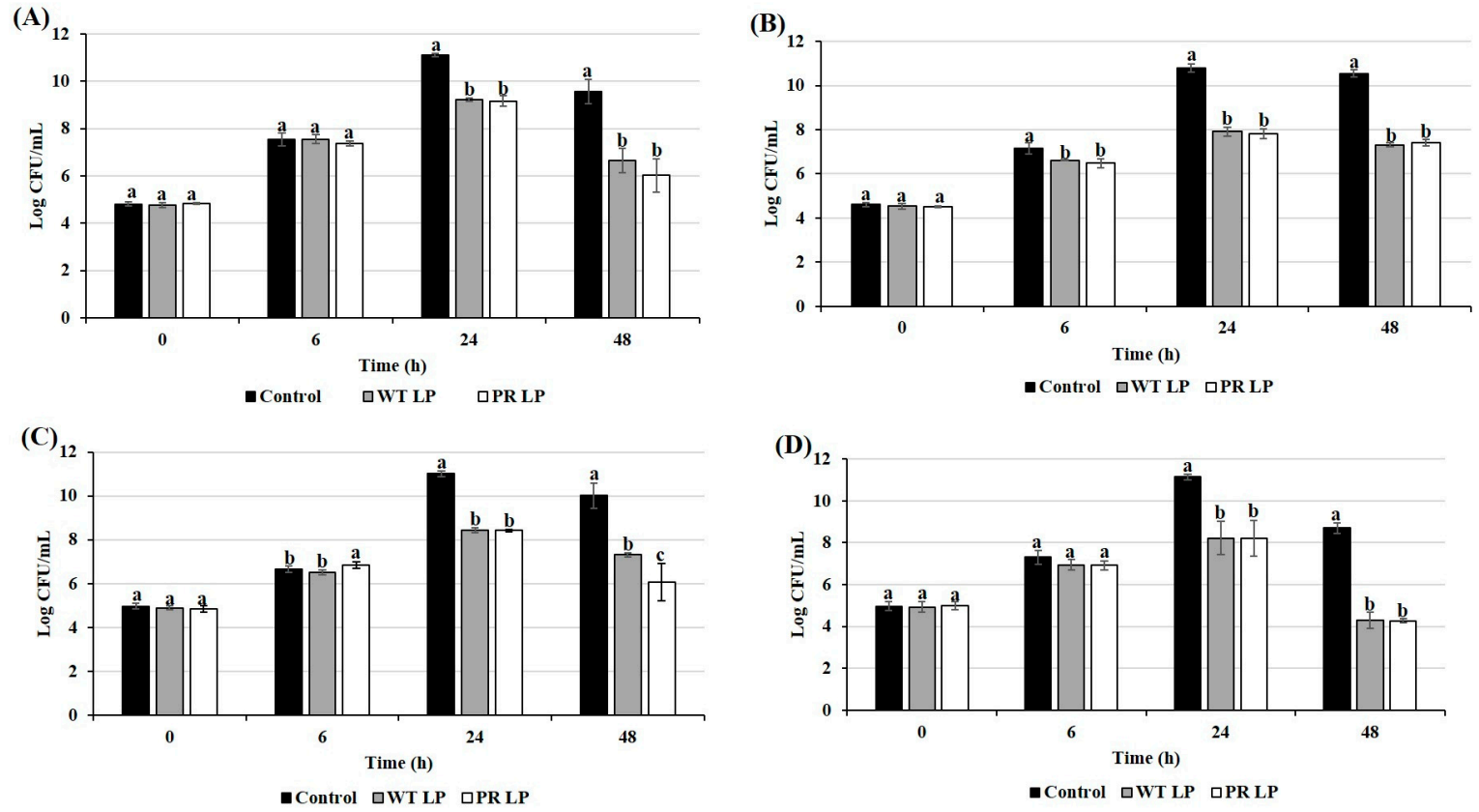

Figure 3. Growth inhibitory effects of cell-free cultural supernatants (CFCSs) from wild-type LP and $\mathrm{LP}^{+P R}$ strains on S. Typhimurium (A), EHEC (B), S. aureus (C), and L. monocytogenes (D) at 0, 6, 24, and $48 \mathrm{~h}$. Error bars indicate standard deviation from 6 parallel trials. Different letters $(\mathrm{a}-\mathrm{c})$ at each time point indicate the significant growth reduction when compared to control at $P<0.05$.

\subsection{Adhesion Abilities of $L P$ and $L P^{+P R}$ to Mammalian Cells}

Adhesion of $\mathrm{LP}^{+P R}$ strain to host cells was examined using human epithelial INT-407 cells (Figure 4). Adhesion abilities of wild-type LP strain were recorded as $6.29 \log \mathrm{CFU} / \mathrm{mL}, 6.77 \log \mathrm{CFU} / \mathrm{mL}$, $6.73 \log \mathrm{CFU} / \mathrm{mL}$ at 2,4 , and $24 \mathrm{~h}$, respectively. Whereas the mutant $\mathrm{LP}^{+P R}$ adhered aggressively to the INT-407 cells at $6.39 \log \mathrm{CFU} / \mathrm{mL}, 6.87 \log \mathrm{CFU} / \mathrm{mL}$, and $6.79 \log \mathrm{CFU} / \mathrm{mL}$ at 2, 4, and $24 \mathrm{~h}$, respectively. We found that $\mathrm{LP}^{+P R}$ strain can adhere more effectively to INT-407 cells compare to wild-type LP strain. However, there is no significant difference between wild-type LP and $L P^{+P R}$ strain.

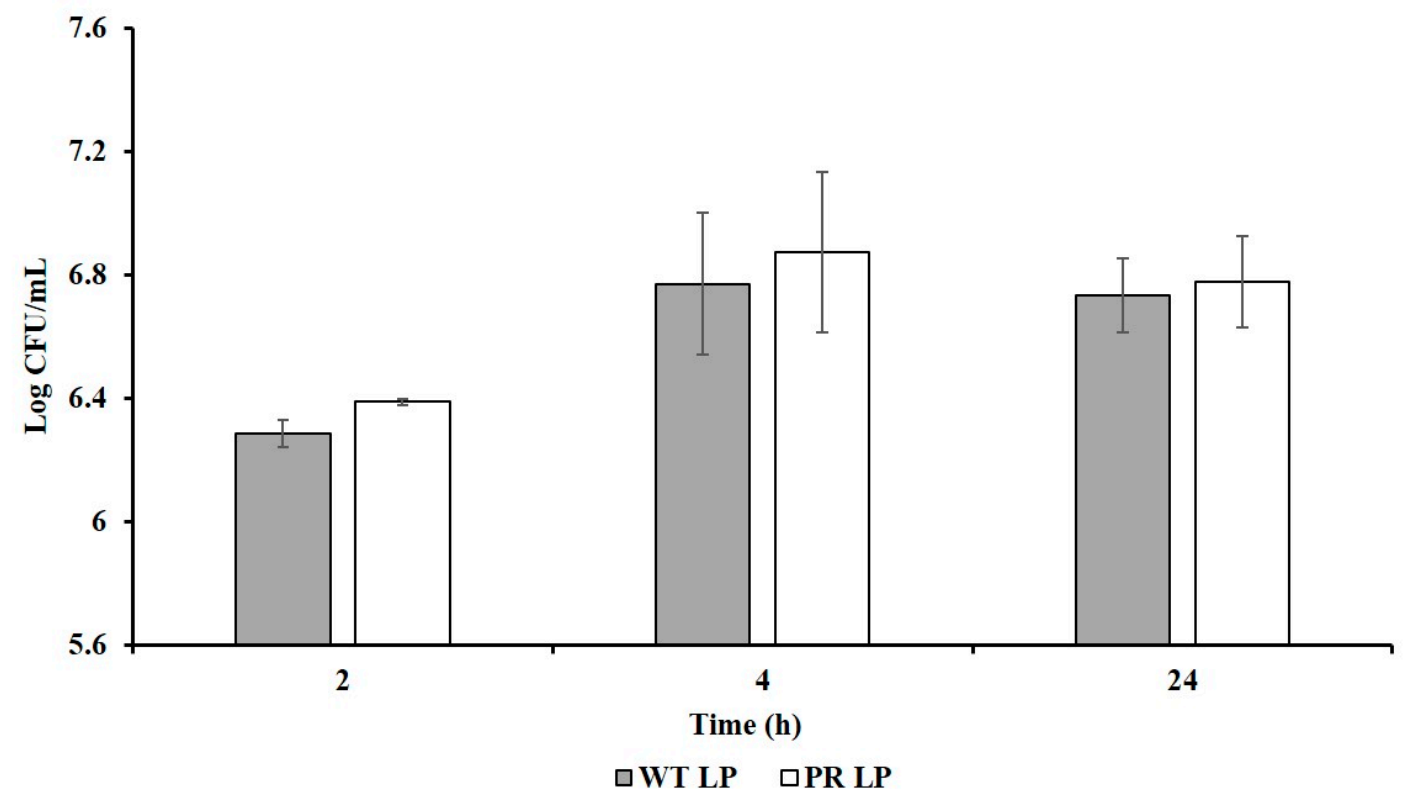

Figure 4. Adherence ability of wild-type LP and LP $+P R$ strains to INT-407 cells. Error bars indicate standard deviation from 6 parallel trials. 


\subsection{Role of $L P$ and $L P^{+P R}$ in Alteration of Pathogen-Host Cell Interactions}

Pre-treatment of INT-407 cells with LP or LP ${ }^{+P R}$ or CFCSs collected from either wild-type LP or mutant $\mathrm{LP}^{+P R}$ strain, reduced both adherence and invasion abilities of $S$. Typhimurium, EHEC, S. aureus, and L. monocytogenes (Figure 5; $P<0.05$ ). It was observed that wild-type LP or mutant $\mathrm{LP}^{+P R}$ strain reduced adhesion abilities of $S$. Typhimurium by 0.81 and $0.88 \log \mathrm{CFU} / \mathrm{mL}$, EHEC by 0.18 and $0.32 \log \mathrm{CFU} / \mathrm{mL}$, S. aureus by 0.93 and $0.85 \log \mathrm{CFU} / \mathrm{mL}$, and L. monocytogenes by 0.45 and $0.44 \log \mathrm{CFU} / \mathrm{mL}$, respectively (Figure 5A). In the presence of CFCSs collected from wild-type LP or mutant $L P^{+P R}$ significantly inhibited adherence activity of 0.41 and $0.43 \log \mathrm{CFU} / \mathrm{mL}$ (S. Typhimurium), 0.50 and $0.54 \log \mathrm{CFU} / \mathrm{mL}$ (EHEC), 0.56 and $0.87 \log \mathrm{CFU} / \mathrm{mL}$ (S. aureus), and 0.83 and $0.89 \log \mathrm{CFU} / \mathrm{mL}$ (L. monocytogenes), respectively (Figure 5C).
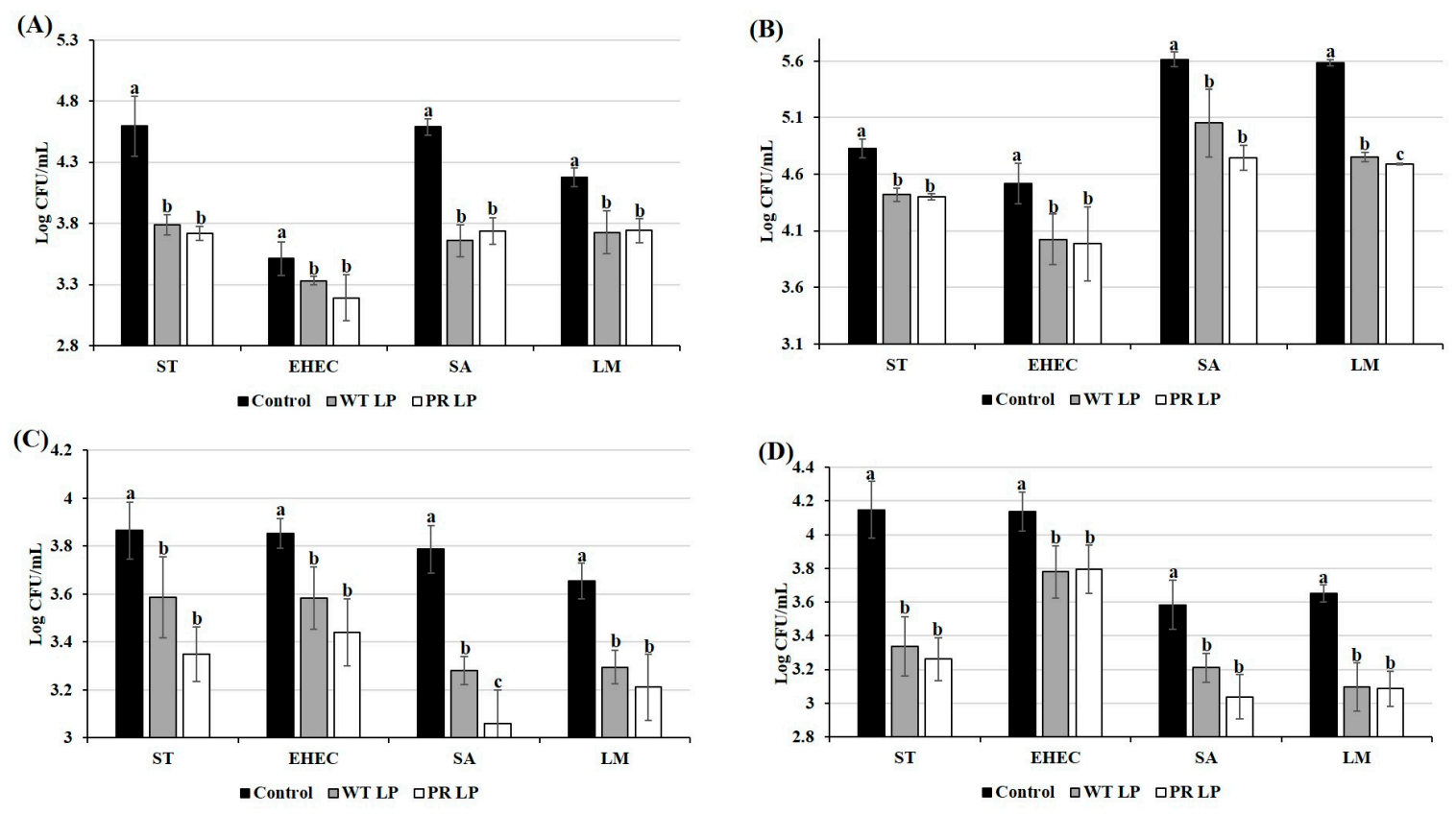

Figure 5. Cell adhesion (A,C) and invasion (B,D) abilities of $S$. Typhimurium, EHEC, S. aureus, and L. monocytogenes to INT-407 cells with pre-treatment of wild-type LP and $L P^{+P R}$ strains $(\mathbf{A}, \mathbf{B})$ and the CFCSs collected from LP and $\mathrm{LP}^{+P R}(\mathbf{C}, \mathbf{D})$. Error bars indicate standard deviation from 6 parallel trials. Different letters $(\mathrm{a}-\mathrm{c})$ are significantly different when compared to control at $P<0.05$.

In the same assay, we found that pre-treatment with wild-type LP or mutant $\mathrm{LP}^{+P R}$ strain significantly reduced invasion abilities of all four pathogens $(0.28$ and $0.52 \log \mathrm{CFU} / \mathrm{mL}$ for S. Typhimurium, 0.27 and $0.41 \log \mathrm{CFU} / \mathrm{mL}$ for EHEC, 0.51 and $0.73 \log \mathrm{CFU} / \mathrm{mL}$ for S. aureus, and 0.36 and $0.44 \log \mathrm{CFU} / \mathrm{mL}$ for L. monocytogenes) at various levels compared to control (Figure 5B). Meanwhile, the invasiveness of L. monocytogenes in the presence of mutant $\mathrm{LP}^{+P R}$ strain was significantly reduced compared to wild-type LP strain (Figure 5B; $P<0.05$ ). We found that invasion abilities of $S$. Typhimurium, EHEC, S. aureus, and L. monocytogenes were reduced significantly in the presence of either CFCSs collected from wild-type $L P$ or $L P^{+P R}$ strains or live probiotics $L P$ or $L P^{+P R}$ at range from $0.5 \log \mathrm{CFU} / \mathrm{mL}$ to $1 \log \mathrm{CFU} / \mathrm{mL}(P<0.05)$ (Figure 5).

\subsection{Alteration of Virulence Gene Expression of Zoonotic Pathogens in Presence of CFCSs Collected from LP and $L P^{+P R}$}

The analysis of virulence gene expression of S. Typhimurium, EHEC, S. aureus, and L. monocytogenes in the presence of CFCSs collected from either wild-type LP or mutant $\mathrm{LP}^{+P R}$ strains is presented in Figure 6. In comparison with control, all four pathogens treated with CFCSs collected from either 
wild-type $\mathrm{LP}$ or mutant $\mathrm{LP}^{+P R}$ altered the expression of tested virulence genes of all four pathogens. In the presence of $\mathrm{LP}$ and $\mathrm{LP}+P R$ CFCSs, the relative expression levels of fliC, fliD, motB, nmpC, hilA, hilD, and mig 5 were significantly downregulated in $S$. Typhimurium. Moreover, a significant downregulation of mig5 was found in $\mathrm{LP}^{+P R}$ when compared to control and wild-type LP strain $(P<0.05)$. For EHEC (Figure 6B), the virulence genes eae $A$, fliC, tir, esp $A$, and $\operatorname{esp} D$ were altered in the presence of CFCSs of wild-type $\mathrm{LP}$ or $\mathrm{LP}^{+P R}$, though no statistically significant differences were found in the relative expression of tir, espA, espD, and fliC. The virulence genes levels of nor $A, \operatorname{nor} B, \operatorname{nor} C, \operatorname{sdr} M$, sep $A$, and $m d e A$ were altered in $S$. aureus when treated with CFCSs collected from either wild-type LP or $\mathrm{LP}^{+P R}$ strains, specifically with a significant fold-change in nor $B, \operatorname{nor} C, \operatorname{sdr} M, \operatorname{sep} A$, and $m d e A$ compared to control $(P<0.05)$. Finally, in the presence of CFCSs of wild-type LP or LP ${ }^{+P R}$, a significant down regulation of $h l y A$, iap, fbp, mot $A$, and motB expressions was found in L. monocytogenes $(P<0.05)$.
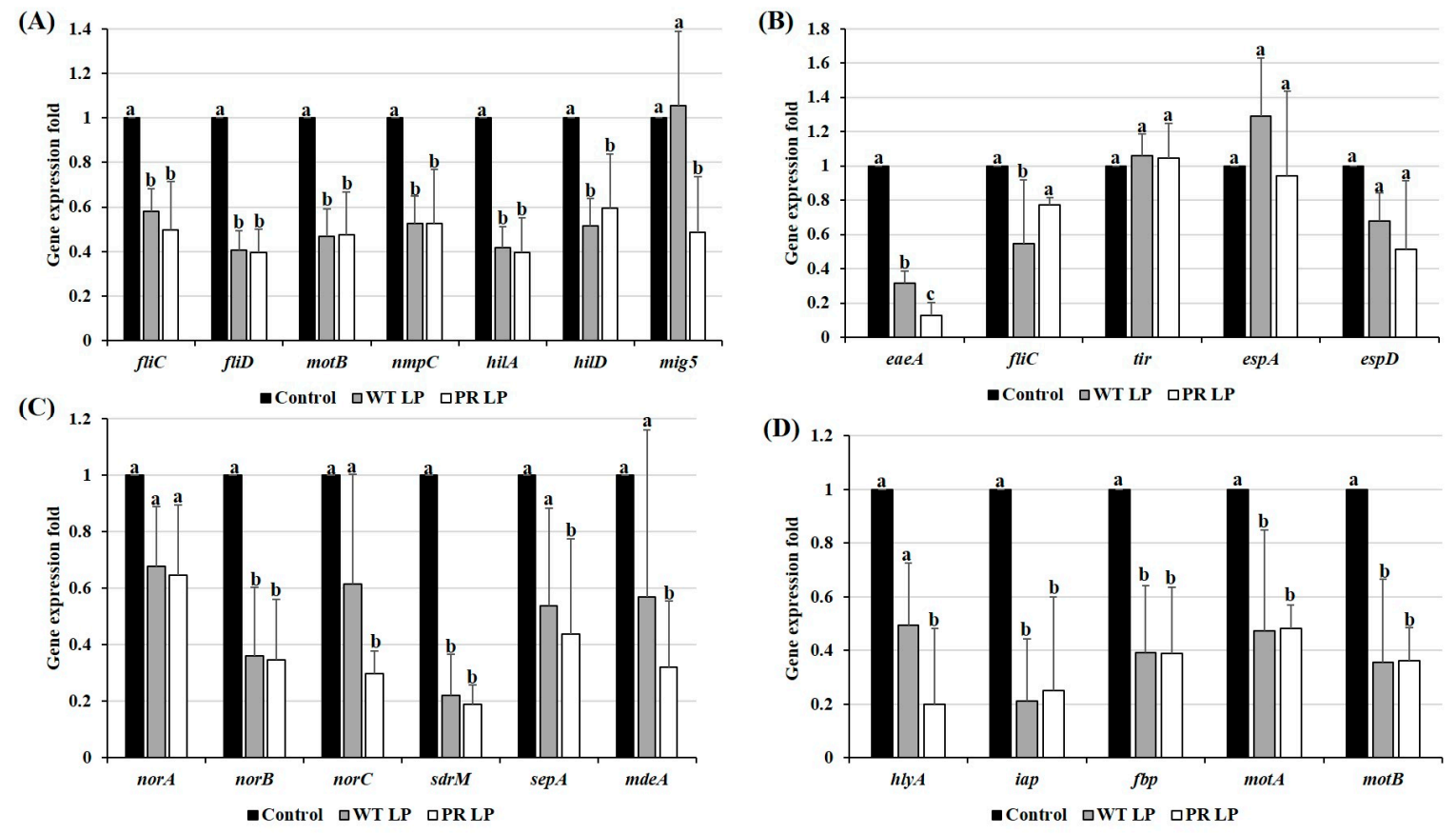

Figure 6. Relative expression of virulence genes of $S$. Typhimurium (A), EHEC (B), S. aureus (C), and L. monocytogenes (D) treated with CFCSs of wild-type LP and $\mathrm{LP}^{+P R}$ strains. Error bars indicate standard deviation from 6 parallel trials. Different letters $(a-c)$ are significantly different at $P<0.05$.

\section{Discussion}

LAB especially LP have the great potential to produce antimicrobial substances which can inhibit the growth of zoonotic bacterial pathogens and prevent them from infections [28]. To provide such benefits to the animal host, probiotics should have properties like ability to adhere and colonize to intestinal cells, produce bio-active metabolites, prevent infection from pathogenic bacteria, survive in acidic environment, and induce immunomodulatory properties. All these beneficial effects could be demolish in the presence specific bacteriophage of the probiotic in the same ecosystem if the introduced probiotic is sensitive to bacteriophage.

To overcome this potential risk, isolation of phage-resistant mutants from phage-sensitive probiotic strains is a convenient, simple and natural approach that has no regulatory restrictions. In the present study, we isolated mutant $\mathrm{LP}^{+P R}$ strain by a soft-agar overlay method and confirmed by bacteriophage gene $p t p$ in the genome of $\mathrm{LP}^{+P R}$ strain. The $\mathrm{LP}^{+P R}$ isolated in this study showed significantly higher survival rate than the phage-sensitive LP strain at $24 \mathrm{~h}$. These results revealed that the $\mathrm{LP}^{+P R}$ isolated in this work exhibited phage gene in the genome and higher growth and survived longer than the phage-sensitive LP strain. 
The adhesive ability of LAB is considered as an important feature for their use of probiotics and it allows the probiotics to exert their benefits on animal host $[5,10]$. In vivo bacterial adherence study was difficult to evaluate due to differentiate from nonadherent bacteria in hosts. Therefore, in vitro cell line model was commonly used to evaluate the adherence level of bacteria. In the present study, we used epithelial INT-407 cells for adherence level of $L P^{+P R}$ strain and compared the adherence level with wild-type LP strain. There were no significant differences amongst adhesion of LP and $\mathrm{LP}^{+P R}$ strains to INT-407 cells. However, $\mathrm{LP}^{+P R}$ strain showed numerically higher adhesion than the wild-type LP strain (Figure 4). Our findings demonstrated that $\mathrm{LP}^{+P R}$ strain could be able to successfully adhere to intestinal epithelial cells. Similar results were reported that phage-resistant L. delbruekii can adhere to colon adenocarcinoma Caco2 intestinal cells [26]. In the same study, they also showed phage-resistant mutant inhibited the adhesion and invasion abilities of the zoonotic enteric pathogen, $S$. Enteritidis to Caco2 cells. The initial step for zoonotic infection is crossing the intestinal epithelial cells in hosts. Reducing enteric pathogen adhesion and invasion to the intestinal epithelium and altering the virulence genes can significantly prevent zoonotic cross-contamination [26].

In the present study, we observed that CFCSs of $L P^{+P R}$ strain reduced the cell attachment and invasive abilities of S. Typhimurium, EHEC, S. aureus, and L. monocytogenes on epithelial INT-407 cells (Figure 5). In addition, adhesion of probiotic bacteria in the gastrointestinal tract stimulating host gut immune responses [29]. Oelschlaeger et al. (2010) [30] demonstrated that production of antimicrobial compounds produced by probiotic bacterial strains contributes to inhibiting on attachment of the pathogenic bacteria. Numerous studies have also shown that organic acids or bacteriocin produced by Lactobacillus may also help in preventing the growth of bacterial enteric pathogens in the animals gut [31,32]. Moreover, another study by Das et al. (2013) [33] reported that CFCS collected from LP inhibited the growth and invasion of Salmonella spp. in HCT-116 colon cells.

Four zoonotic enteric bacterial pathogens were investigated for their virulence gene expression in the presence of CFCSs collected from LP or $L P^{+P R}$ strain. Based on our results, we found that all the targeted virulence genes were significantly altered the expression by CFCSs of LP or LP The virulence gene of flagella has been well studied in S. Typhimurium [34]. Flagella can play an important role in colonization by providing motility to target cells, and receptors and motility genes were shown to be essential for invade into cultured epithelial cells [35]. In this study, virulence genes of $S$. Typhimurium $f l i C$, fliD, motB, nmpC, hilA, hilD, and mig 5 were found to be downregulated by $\mathrm{LP}^{+P R}$. Therefore, alteration of these genes could lead to reduced attachment and invasive abilities of $S$. Typhimurium to the host cells. The locus of enterocyte effacement Pathogenicity Island which encodes two genes, eae (intimin) and tir (translocated intimin receptor), has been reported to play important role in EHEC pathogenesis and form attaching and effacing in various in vitro cell culture models [36]. Downregulation of EHEC intimin virulence gene in the presence of CFCSs collected from $\mathrm{LP}^{+P R}$ provide us an explanation for the reduced cell adhesion and invasion to the host cells. Multi-drug resistance (MDR) efflux pump genes in S. aureus have been well studied and are responsible for resistance to multiple antibiotics especially methicillin [37-40].

Moreover, these MDR efflux pump genes are involved in an increased virulence activity in S. aureus to the host's gastrointestinal tract. In order to assess the roles of CFCSs of $L P^{+P R}$ against $S$. aureus, we selected MDR efflux pump genes nor $A$, norB, norC, $\operatorname{sdrM}$, sep $A$, as well as methicillin resistance mediatory gene mec $A$ in the presence of CFCSs from $\mathrm{LP}^{+P R}$ strain. A significant alteration of MDR efflux pump genes and mecA gene were detected when the $S$. aureus was pretreated with CFCSs of LP or LP ${ }^{+P R}$. Fournier and Hooper, (2000) [41] investigated MDR efflux genes and found that they can be involved in S. aureus adhesion. Flagella and motility related genes from L. monocytogenes are essential for initial cell surface attachment and cell invasion activities [42,43]. Therefore, we tested the L. monocytogenes virulence genes such as $h l y A$, iap, fbp, mot $A$, and motB in the presence of CFCSs of $\mathrm{LP}^{+P R}$. Remarkably, the virulence gene expression was significantly downregulated by $\mathrm{LP}^{+P R}$ strain. These virulence genes results are correlated with cell adhesion and invasion abilities of $S$. Typhimurium, 
EHEC, S. aureus, and L. monocytogenes to INT-407 cells. The results from our study clearly demonstrate that mutant $\mathrm{LP}^{+P R}$ strain showed similar or better probiotic properties than wild-type LP strain.

In summary, the present work demonstrated that the bacteriophage resistance $\mathrm{LP}^{+P R}$ strain can grow faster than wild-type LP strain and inhibited the growth and survival of $S$. Typhimurium, EHEC, S. aureus, and L. monocytogenes. Based on the in vitro results, $\mathrm{LP}^{+P R}$ shows promising probiotic functional properties. Specifically, $\mathrm{LP}^{+P R}$ was able to adhere to epithelial cells and reduced the adherence and invasion abilities of $S$. Typhimurium, EHEC, S. aureus, and L. monocytogenes to INT-407 cells. Thus, the $\mathrm{LP}^{+P R}$ strain could be a potential candidate for further in vivo studies to development of potential probiotic strain in feed supplement of farm animal production.

Supplementary Materials: The following are available online at http://www.mdpi.com/2304-8158/8/6/194/s1, Figure S1: PCR confirmation of LP+PR strain. 1\% Agarose gel electrophoresis analysis of total DNA extracted from bacteriophage J1 (lane 1), LP+PR strains (lanes 2-4), and wild-type LP strain (lane 5). M, 1 kb marker ladder.

Author Contributions: Conceptualization, D.B.; writing—original draft preparation, V.N.; writing—review and editing, D.B and M.P.; formal analysis and methodology, V.N.; S.S.; Z.T.; J.P.; supervision, D.B.

Funding: Not applicable.

Acknowledgments: This work was supported by Center for Food Safety and Security Systems (CFS), University of Maryland, College Park, MD. We would like to thank our undergraduate interns specifically Ahlam Akmel, Ashley Houser, Jacob Bhatti, and Avinaash Sandhu, University of Maryland, College Park, MD for assistance with experiment.

Conflicts of Interest: The authors declare no conflict of interest.

\section{References}

1. Asmahan, A. Beneficial role of lactic acid bacteria in food preservation and human health: A review. Res. J. Microbiol. 2010, 5, 1213-1221. [CrossRef]

2. Fijan, S. Microorganisms with claimed probiotic properties: An overview of recent literature. Int. J. Environ. Res. Public Health 2014, 11, 4745-4767. [CrossRef] [PubMed]

3. Upadrasta, A.; Stanton, C.; Hill, C.; Fitzgerald, G.F.; Ross, R.P. Improving the stress tolerance of probiotic cultures: Recent trends and future directions. In Stress Responses of Lactic Acid Bacteria; Tsakalidou, E., Papadimitriou, K., Eds.; Springer: New York, NY, USA, 2011; pp. 395-438.

4. Šuškoviæ, J.; Kos, B.; Beganoviæ, J.; Pavunc, A.L.; Habjaniè, K.; Matošiæ, S. Antimicrobial activity-The most important property of probiotic and starter lactic acid bacteria. Food Technol. Biotechnol. 2010, 48, 296-307.

5. Peng, M.; Biswas, D. Short chain and polyunsaturated fatty acids in host gut health and foodborne bacterial pathogen inhibition. Crit. Rev. Food Sci. Nutr. 2016, 57, 3987-4002. [CrossRef] [PubMed]

6. Duary, R.K.; Bhausaheb, M.A.; Batish, V.K.; Grover, S. Anti-inflammatory and immunomodulatory efficacy of indigenous probiotic Lactobacillus plantarum Lp91 in colitis mouse model. Mol. Biol. Rep. 2012, 39, 4765-4775. [CrossRef] [PubMed]

7. Kumar, R.; Grover, S.; Batish, V.K. Hypocholesterolaemic effect of dietary inclusion of two putative probiotic bile salt hydrolase producing Lactobacillus plantarum strains in Sprague-Dawley rats. Br. J. Nutr. 2011, 105, 561-573. [CrossRef] [PubMed]

8. Szilagyi, A.; Shrier, I.; Heilpern, D.; Je, J.; Park, S.; Chong, G.; Lalonde, C.; Cote, L.F.; Lee, B. Differential impact of lactose/lactase phenotype on colonic microflora. Can. J. Gastroenterol. 2010, 24, 373-379. [CrossRef] [PubMed]

9. Rerksuppaphol, S.; Rerksuppaphol, L. A randomized double-blind controlled trial of Lactobacillus acidophilus plus Bifidobacterium bifidum versus placebo in patients with hypercholesterolemia. J. Clin. Diagn. Res. 2015, 9, KC01-KC04. [CrossRef] [PubMed]

10. Kabir, S.M. The Role of Probiotics in the Poultry Industry. Int. J. Mol. Sci. 2009, 10, 3531-3546. [CrossRef]

11. Zago, M.; Fornasari, M.E.; Carminati, D.; Bums, P.; Suàrez, V.; Vinderola, G.; Reinheimer, J.; Giraffa, G. Characterization and probiotic potential of Lactobacillus plantarum strains isolated from cheeses. Food Microbiol. 2011, 28, 1033-1040. [CrossRef]

12. Georgieva, R.; Iliev, I.; Haertlé, T.; Chobert, J.M.; Ivanova, I.; Danova, S. Technological properties of candidate probiotic Lactobacillus plantarum strains. Int. Dairy J. 2009, 19, 696-702. [CrossRef] 
13. Karimi, S.; Azizi, F.; Nayeb-Aghaee, M.; Mahmoodnia, L. The antimicrobial activity of probiotic bacteria Escherichia coli isolated from different natural sources against hemorrhagic E. coli O157:H7. Electron. Physician 2018, 10, 6548-6553. [CrossRef] [PubMed]

14. Wang, L.; Li, L.; Lv, Y.; Chen, Q.; Feng, J.; Zhao, X. Lactobacillus plantarum Restores Intestinal Permeability Disrupted by Salmonella Infection in Newly-hatched Chicks. Sci. Rep. 2018, 8, 2229. [CrossRef] [PubMed]

15. Sikorska, H.; Smoragiewicz, W. Role of probiotics in the prevention and treatment of meticillin-resistant Staphylococcus aureus infections. Int. J. Antimicrob. Agents 2013, 42, 475-481. [CrossRef] [PubMed]

16. Geeta, P.; Yadav, A.S. Antioxidant and antimicrobial profile of chicken sausages prepared after fermentation of minced chicken meat with Lactobacillus plantarum and with additional dextrose and starch. LWT-Food Sci. Technol. 2017, 77, 249-258. [CrossRef]

17. Parvez, S.; Malik, K.A.; Ah Kang, S.; Kim, H.Y. Probiotics and their fermented food products are beneficial for health. J. Appl. Microbiol. 2006, 100, 1171-1185. [CrossRef] [PubMed]

18. Candela, M.; Perna, F.; Carnevali, P.; Vitali, B.; Ciati, R.; Giochetti, P.; Rizzello, F.; Campieri, M.; Brigidi, P. Interaction of probiotic Lactobacillus and Bifidobacterium strains with human intestinal epithelial cells: Adhesion properties, competition against enteropathogens and modulation of IL-8 production. Int. J. Food Microbiol. 2008, 125, 286-292. [CrossRef]

19. Emond, E.; Moineau, S. Bacteriophages and food fermentations. In Bacteriophage: Genetics and Molecular Biology; McGrath, S., van Sinderen, D., Eds.; Horizon Scientific Press/Caister Academic Press: Norfolk, UK, 2007; pp. 93-124.

20. Samson, J.E.; Moineau, S. Bacteriophages in food fermentations: New frontiers in a continuous arms race. Annu. Rev. Food Sci. Technol. 2013, 4, 347-368. [CrossRef]

21. Ahn, J.; Kim, S.; Jung, L.; Biswas, D. Effect of bacteriophage on the transcriptional and translational expression of inflammatory mediators in chicken macrophage. J. Poult. Sci. 2014, 51, 96-103. [CrossRef]

22. Peng, M.; Reichmann, G.; Biswas, D. Lactobacillus casei and its byproducts alter the virulence factors of foodborne bacterial pathogens. Funct. Foods 2015, 15, 418-428. [CrossRef]

23. Guglielmotti, D.M.; Reinheimer, J.A.; Binetti, A.G.; Giraffa, G.; Carminati, D.; Quiberoni, A. Characterization of spontaneous phage-resistant derivatives of Lactobacillus delbrueckii commercial strains. Int. J. Food Microbiol. 2006, 111, 126-133. [CrossRef]

24. Peng, M.; Aryal, U.; Cooper, B.; Biswas, D. Metabolites produced during the growth of probiotics in cocoa supplementation and the limited role of cocoa in host-enteric bacterial pathogen interactions. Food Control 2015, 53, 124-133. [CrossRef]

25. Tabashsum, Z.; Peng, M.; Salaheen, S.; Comis, C.; Biswas, D. Competitive elimination and virulence property alteration of Campylobacter jejuni by genetically engineered Lactobacillus casei. Food Control 2018, 85, 283-291. [CrossRef]

26. Guglielmotti, D.M.; Marco, M.B.; Golowczyb, M.; Treinherimer, J.A.; Quiberoni, A.L. Probiotic potential of Lactobacillus delbrueckii strains and their phage resistant mutants. Int. Dairy J. 2007, 17, 916-925. [CrossRef]

27. Livak, K.J.; Schmittgen, T.D. Analysis of relative gene expression data using real-time quantitative PCR and the $2^{-\Delta \Delta C T}$ Method. Methods 2001, 25, 402-408. [CrossRef]

28. Tufail, M.; Hussain, S.; Malik, F.; Mirza, T.; Parveen, G.; Shafaat, S.; Wajid, A.; Mahmood, R.; Channa, R.A.; Sadiq, A. Isolation and evaluation of antibacterial activity of bacteriocin produced by Lactobacillus bulgaricus from yogurt. Afr. J. Microbiol. Res. 2011, 5, 3842-3847. [CrossRef]

29. Hemarajata, P.; Versalovic, J. Effects of probiotics on gut microbiota: Mechanisms of intestinal immunomodulation and neuromodulation. Ther. Adv. Gastroenterol. 2013, 6, 39-51. [CrossRef]

30. Oelschlaeger, T.A. Mechanisms of probiotic actions-A Review. Int. J. Med. Microbiol. 2010, 300, 57-62. [CrossRef]

31. Ben Lagha, A.; Haas, B.; Gottschalk, M.; Grenier, D. Antimicrobial potential of bacteriocins in poultry and swine production. Vet. Res. 2017, 48, 22. [CrossRef]

32. Neal-McKinney, J.M.; Lu, X.; Duong, T.; Larson, C.L.; Call, D.R.; Shah, D.H.; Konkel, M.E. Production of organic acids by probiotic Lactobacilli can be used to reduce pathogen load in poultry. PLoS ONE 2012, 7, e43928. [CrossRef]

33. Das, J.K.; Mishra, D.; Ray, P.; Tripathy, P.; Beuria, T.K.; Singh, N.; Suar, M. In vitro evaluation of anti-infective activity of a Lactobacillus plantarum strain against Salmonella enterica serovar Enteritidis. Gut Pathog. 2013, 5, 11. [CrossRef] 
34. Ikeda, J.S.; Schmitt, C.K.; Darnell, S.C.; Watson, P.R.; Bispham, J.; Wallis, T.S.; Weinstein, D.L.; Metcalf, E.S.; Adams, P.; O'Connor, C.D.; et al. Flagellar phase variation of Salmonella enterica serovar Typhimurium contributes to virulence in the murine typhoid infection model but does not influence Salmonella-induced enteropathogenesis. Infect. Immun. 2001, 69, 3021-3030. [CrossRef] [PubMed]

35. Haiko, J.; Westerlund-Wikstrom, B. The role of the bacterial flagellum in adhesion and virulence. Biology 2013, 2, 1242-1267. [CrossRef] [PubMed]

36. Donnenberg, M.S.; Tzipori, S.; McKee, M.L.; O'Brien, A.D.; Alroy, J.; Kaper, J.B. The role of the eae gene of enterohemorrhagic Escherichia coli in intimate attachment in vitro and in a porcine model. J. Clin. Investig. 1993, 92, 1418-1424. [CrossRef]

37. Fournier, B.; Aras, R.; Hooper, D.C. Expression of the multidrug resistance transporter NorA from Staphylococcus aureus is modified by a two-component regulatory system. J. Bacteriol. 2000, 182, 664-671. [CrossRef] [PubMed]

38. Truong-Bolduc, Q.C.; Strahilevitz, J.; Hooper, D.C. NorC, a new efflux pump regulated by MgrA of Staphylococcus aureus. Antimicrob. Agents Chemother. 2006, 50, 1104-1107. [CrossRef]

39. Mazurkiewicz, P.; Sakamoto, K.; Poelarends, G.J.; Konings, W.N. Multidrug transporters in lactic acid bacteria. Mini Rev. Med. Chem. 2005, 5, 173-181. [CrossRef]

40. Salaheen, S.; Peng, M.; Joo, J.; Teramoto, H.; Biswas, D. Eradication and sensitization of methicillin resistant Staphylococcus aureus to methicillin with bioactive extracts of berry pomace. Front. Microbiol. 2017, 8, 253. [CrossRef]

41. Fournier, B.; Hooper, D.C. A new two-component regulatory system involved in adhesion, autolysis and extracellular proteolytic activity of Staphylococcus aureus. J. Bacteriol. 2000, 182, 3955-3964. [CrossRef]

42. Marini, E.; Magi, G.; Ferretti, G.; Bacchetti, T.; Giuliani, A.; Pugnaloni, A.; Rippo, M.R.; Facinelli, B. Attenuation of Listeria monocytogenes virulence by Cannabis sativa L. essential oil. Front. Cell. Infect. Microbiol. 2018, 8, 293. [CrossRef]

43. Lemon, K.P.; Higgins, D.E.; Kolter, R. Flagellar motility is critical for Listeria monocytogenes biofilm formation. J. Bacteriol. 2007, 189, 4418-4424. [CrossRef] [PubMed]

(C) 2019 by the authors. Licensee MDPI, Basel, Switzerland. This article is an open access article distributed under the terms and conditions of the Creative Commons Attribution (CC BY) license (http://creativecommons.org/licenses/by/4.0/). 